\title{
Microbiological Evaluation of Imported Frozen Mussels and Locally Harvested Black Bea Mussels
}

\author{
Mara GEORGESCU ${ }^{*}$, Mimi DOBREA ${ }^{2}$, Iuliana NEAGU ${ }^{2}$, Anca Alexandra DOBREA (POPESCU) ${ }^{2}$, Rosalie \\ DOJANĂ $\breve{A}^{2}$ \\ ${ }^{1}$ Department of Animal Production and Public Health. USAMV Bucharest, Romania. \\ ${ }^{2}$ Department of Preclinical Sciences, USAMV Bucharest, Romania. \\ Corresponding author: dr_georgescu_mara@yahoo.com
}

Bulletin UASVM Veterinary Medicine 72(1) / 2015,

Print ISSN 1843-5270; Electronic ISSN 1843-5378

DOI:10.15835/buasvmcn-vm: 10346

\begin{abstract}
Mussels are increasing in popularity and availability throughout the world, becoming a part of the international menu, in various forms, leading to a growing interest in their food safety profiling, which remains in the spotlight of current research.

The microbiological quality of frozen mussels sold in retail stores was compared with that of locally harvested, fresh mussels.

Samples of frozen, processed mussels and Black Sea mussels were analyzed in terms of coliforms and aerobic plate count (APC), according to the national standards for APC and coliforms' enumeration method (SR ISO 4833/2003 and SR ISO 4832:2009, respectively). The results were statistically analyzed using univariate un-paired $\mathrm{t}$ tests. We considered $\mathrm{p}<0.05$ to be statistically significant. SPSS statistical software was used for data analysis.

The aerobic plate counts were higher for processed, frozen mussels than for the samples of locally harvested Black Sea mussels. The difference is considered to be extremely statistically significant $(\mathrm{p}<0.0001, t=5.7465$, $\mathrm{DF}=9$ ). The coliforms' counts were also higher for the frozen mussel samples, than for the samples of locally harvested Black Sea mussels, but the difference was not statistically significant $(p=0.0641, t=1.9724, D F=9)$.

The overall results indicate that locally harvested Black Sea mussels are less contaminated than imported, processed, frozen mussels.
\end{abstract}

Keywords: APC, coliforms, mussels.

\section{INTRODUCTION}

Mussels are an increasingly appreciated food available on the market as processed frozen product, fresh harvest of seashore areas and even street food. Research regarding the microbiological pathogens and contaminants in such seafood is being intensively communicated aiming the evaluation of the food safety profile. The covered topics discussed by researchers vary from the microbiological evaluation of stuffed mussels, marketed as street food, at high temperatures (Kişla and Uzgün, 2008; Ates et al., 2001), the microbiological quality of raw oysters harvested from different cost sites (Changchai and Saunjit, 2014; Mannas et al., 2014) etc.

\section{AIMS AND OBJECTIVES}

The microbiological quality of frozen mussels sold in retail stores was compared with that of locally harvested, fresh mussels.

\section{MATERIALS AND METHODS}

Ten samples of frozen, processed mussels (commercial packs) and ten samples of Black Sea mussels (Mytilus galloprovincialis) harvested by local fishermen from Constanta county seashore waters, were analyzed in terms of coliforms and aerobic plate count (APC). The microbial hazard laboratory analysis was performed according to the national standards for APC and coliforms' 
Tab. 1. The results of the coliforms and APC contamination investigation in locally harvested and frozen mussels, statistically analyzed using the univariate un-paired t test .

\begin{tabular}{ccccc}
\hline & \multicolumn{2}{c}{ APC $(\log$ CFU/g) } & \multicolumn{2}{c}{ coliforms (log CFU/g) } \\
\hline & frozen & local harvest & frozen & local harvest \\
\hline 1 & 3,54 & 2,71 & 1,8 & 1,2 \\
\hline 3 & 4,2 & 2,4 & 1,59 & 0,65 \\
\hline 4 & 3,21 & 1,98 & 1,24 & 1,14 \\
\hline 5 & 4,2 & 2,59 & 2 & 0,8 \\
\hline 6 & 3,96 & 2,83 & 1,86 & 0,69 \\
\hline 7 & 3,42 & 3,1 & 1,32 & 2,3 \\
\hline 8 & 2,9 & 2,7 & 0,94 & 1,18 \\
\hline 9 & 3,8 & 1,4 & 2,1 & 0,4 \\
\hline 10 & 4,52 & 2,25 & 1,78 & 0,52 \\
\hline STD & 3,32 & 1,8 & 1,39 & 2,3 \\
\hline AVG & 3,514027 & 0,521775 & 0,370849 & 0,681645 \\
\hline p value & 3,707 & 2,376 & 1,602 & 1,118 \\
\hline
\end{tabular}

enumeration method (SR ISO 4833/2003 and SR ISO 4832:2009, respectively). The results were statistically analyzed using univariate un-paired $\mathrm{t}$ tests. We considered $\mathrm{p}<0.05$ to be statistically significant. SPSS statistical software was used for data analysis.

\section{RESULTS AND DISCUSSION}

The aerobic plate counts were higher for processed, frozen mussels (average of $3.7 \mathrm{log}$ $\mathrm{CFU} / \mathrm{g}, \mathrm{SD}=0,514$ ) than for the samples of locally harvested Black Sea mussels (average of 2.3 log $\mathrm{CFU} / \mathrm{g}, \mathrm{SD}=0.521$ ). The result analysis revealed that the difference is considered to be extremely statistically significant $(\mathrm{p}<0.0001, \mathrm{t}=5.7465$, $\mathrm{DF}=9$ ). The coliforms' counts were also higher for the frozen mussel samples (average of $1.6 \mathrm{log}$ $\mathrm{CFU} / \mathrm{g}, \mathrm{SD}=0.37$ ) than for the samples of locally harvested Black Sea mussels (average of $1.1 \mathrm{log}$ $\mathrm{CFU} / \mathrm{g}, \mathrm{SD}=0.681$ ), but the difference was not statistically significant $(\mathrm{p}=0.0641, \mathrm{t}=1.9724$, $\mathrm{DF}=9$ ).

Many authors reveal significant levels of bacterial or viral contamination in raw frozen mussels or oysters (Changchai and Saunjit, 2014; Mannas et al., 2014), advising to proper cooking of such foods, whilst insufficient data is available on the effect of freezing and retail stores marketing on the overall microbiological quality of mussels. Therefore this study is relevant for comparing the microbiological quality of freshly harvested mussels with that of frozen, packed mussels and revealing lower contamination levels in Black Sea freshly harvested mussels.

\section{CONCLUSION}

The overall results of this investigation indicate that locally harvested Black Sea mussels are less contaminated than imported, processed, frozen mussels.

\section{REFERENCES}

1. Ates M, Ozkizilcik A, Tabakoglu C (2011). Microbiological analysis of stuffed mussels sold in the streets, Indian J Microbiol. 51(3):350-4. doi: 10.1007/s12088-011-01746. Epub 2011.

2. Changchai N, Saunjit S (2014). Occurrence of Vibrio parahaemolyticus and Vibrio vulnificus in retail raw oysters from the eastern coast of Thailand, Southeast Asian J Trop Med Public Health. 45(3):662-9.

3. Kişla D, Uzgün Y (2008). Microbiological evaluation of stuffed mussels, J Food Prot 71(3):616-20.

4. Mannas H, Mimouni R, Chaouqy N, Hamadi F, MartinezUrtaza J (2014). Occurrence of Vibrio and Salmonella species in mussels (Mytilus galloprovincialis) collected along the Moroccan Atlantic coast. Springerplus. 24;3:265. doi: 10.1186/2193-1801-3-265. 